\title{
Through the looking glass of Bhils-How Markets win what the State has lost in the desert jungles of Western Rajasthan
}

\section{Bobby Luthra Sinha ${ }^{1}$ Universidad de Basilea, Suiza}

\section{Artículo científico}

Material original autorizado para su primera publicación en el Journal de Ciencias Sociales, Revista Académica de la Facultad de Ciencias Sociales de la Universidad de Palermo.

Recibido: 26-8-2017

Aceptado: 5-9-2017

\section{Abstract}

Based on the author's field work in western Rajasthan, this paper forwards the argument that the growing chasm between its promises and delivery has made the state lose its credibility among the Bhils of western Rajasthan in India. The interviews and observations are based on twelve weeks of participation in the daily life of multiple actors in desert jungles of Jodhpur and Bikaner western Rajasthan. The main motive was to understand various postures on hunting- as a community activity as well as a legal input behind certain modern state laws. Still waiting for basic amenities such as reliable supply of water and electricity, forest communities as Bhils also remain unhappy with the way the power politics amongst caste plays out to suppress their ascent into public offices. Many practices of the state remain out of bounds for them. In as far as evoking from the state a moral-functional response over its failings is concerned, Bhils see no light at the end of the day either. They substantiate this by pointing out that, perhaps, their demands, requirements and expectations from the state still remain pretty much the same as the promises in the inaugural election manifestos of parties post-independence. However, although they find it hard to reach the state, its reciprocal reach towards intervening in day to day lives of the communities remains much more than its own ability to deliver for them. This is evidenced by the helicopter visions emanating from changed hunting laws which in turn change the way Bhils view the state and society around them. While Bhils come to terms with or question these laws in India, the irony is that the hunting of the very species which stands declared as under threat stands hunted clandestinely on ground by all kinds of actors, despite a 'jail without bail' provision that presumably should up the ante for criminal activities such as poaching. In this context this paper talks of the world view of the Bhils over the issue

${ }^{1}$ Dra. en Antropología, Universidad de Basilea, Suiza. BA en Ciencias Políticas, Universidad de Delhi, Correo electrónico: blenarg@yahoo.com 
in general, their dilemmas and emic perspectives in particular. It also brings to light the implications of conservation politics by other communities in the vicinity such as the Bishnois who wage collective struggles to ensure protection of endangered species, while the state remains distant and lags behind in its approach to answer the issues raised by the Bhils, newer market strategies and products gain a quick entry as well as growing relevance in the Bhil lifestyles.

Keywords: Political Imagery and Reverse Integration of Bhils; Historicity; Caste; Hunting; and the Rule of Law.

\section{Resumen}

Basado en el trabajo de campo del autor en el oeste de Rajastán, este artículo persigue el argumento de que el creciente abismo entre sus promesas y su concreción ha hecho que el estado pierda su credibilidad entre los Bhils de Rajastan occidental en la India. Las entrevistas y observaciones se basan en doce semanas de participación en la vida cotidiana de múltiples actores en las selvas del desierto de Jodhpur y Bikaner en el oeste de Rajastan. El motivo principal era entender varias posturas sobre la caza, como una actividad comunitaria, así como un aporte legal detrás de ciertas leyes estatales modernas. Todavía a la espera de servicios básicos como el suministro confiable de agua y electricidad, las comunidades forestales como los Bhils también siguen descontentos con la forma en que la política entre casta juega a suprimir su ascenso en las oficinas públicas. Muchas prácticas del estado permanecen fuera de límites para ellos. En cuanto a la evocación del estado una respuesta moral-funcional sobre sus fallas se refiere, los Bhils no ven ninguna luz al final del día tampoco. Ellos lo sustentan señalando que, quizás, sus demandas, requerimientos y expectativas del Estado siguen siendo prácticamente iguales a las promesas en los manifiestos electorales inaugurales de los partidos después de la independencia. Sin embargo, aunque les resulta difícil llegar al estado, su alcance recíproco para intervenir en la vida cotidiana de las comunidades sigue siendo mucho más que su propia capacidad de entrega para ellos. Esto se evidencia por las visiones del helicóptero que emanan de las leyes cambiantes de la caza que a su vez cambian la manera en que Bhils ven el estado y la sociedad alrededor de ellos. Mientras que los Bhils llega a un acuerdo con o cuestiona estas leyes en la India, la ironía es que la caza de la misma especie que se declara como amenazada es cazada clandestinamente en tierra por todo tipo de actores, a pesar de una "cárcel sin fianza" debe subir la apuesta para actividades criminales como la caza furtiva. En este contexto, este documento habla de la visión mundial de los Bhils sobre el tema en general, sus dilemas y perspectivas emic en particular. También trae a la luz las implicaciones de las políticas de conservación por otras 
comunidades en las cercanías, como los bishnois que llevan a cabo luchas colectivas para garantizar la protección de las especies en peligro, mientras que el estado sigue distante y evita responder a las cuestiones planteadas por los Bhils, las nuevas estrategias de mercado y los productos ganan una entrada rápida, así como la creciente relevancia en los estilos de vida de Bhil.

Palabras clave: imaginario político e integración inversa, historicidad, casta, caza, imperio de la ley.

\section{Part I Themes and Methodology}

Based on the author's field work in western Rajasthan, this paper forwards the argument that the growing chasm between its promises and deliveryhas made the state lose its credibility among the Bhils of western Rajasthan in India. The interviews and observations are based on twelve weeks of participation in the daily life of multiple actors in desert jungles of Jodhpur and Bikaner western Rajasthan. The main motive was to understand various postures on hunting- as a community activity as well as a legal input behind certain modern state laws. Still waiting for basic amenities such as reliable supply of water and electricity, forest communities as Bhilsalso remain unhappy with the way the power politics amongst caste plays out to suppress their ascent into public offices. Many practices of the state remain out of bounds for them. In as far as evoking from the state a moral-functional response over its failings is concerned, Bhils see no light at the end of the day either. They substantiate this by pointing out that, perhaps, their demands, requirements and expectations from the state still remain pretty much the same as the promises in the inaugural election manifestos of parties post-independence.

However, although they find it hard to reach the state, its reciprocal reach towards intervening in day to day lives of the communities remains much more than its own ability to deliver for them. This is evidenced by the helicopter visions emanating from changed hunting laws which in turn change the way Bhils view the state and society around them. While Bhils come to terms with or question these laws in India, the irony is that the hunting of the very species which stands declared as under threat stands hunted clandestinely on ground by all kinds of actors, despite a 'jail without bail' provision that presumably should up the ante for criminal activities such as poaching. In this context this paper talks of the world view of the Bhils over the issue in general, their dilemmas and emic perspectives in particular. It also brings to light the implications of conservation politics by other communities in the vicinity such as the Bishnois who wage collective struggles to ensure protection of endangered species. On the one hand actors such as Bishnois through their action demand that the cause of integrating the Bhils be taken up by the authorities and rightful funds and 
policies be released for making the decision making processes At the same time, the paper shows how, while the state remains distant and lags behind in its approach to answer the issues raised by the Bhils, newer market strategies and products gain a quick entry as well as growing relevance in the Bhil lifestyles.

Emic Evaluation Approach (EEA):The methodological tools and conception were inspired mainly from the perspectives of the Emic Evaluation Approach or the EEA. The EEA is a multi-actor, multi-method, ethnographic approach that moves through a circular investigation for data collection, organization and analysis. It entails three nodal aspects in data collection and research- actor analysis, social discourse analysis and practice analysis. Although initially it was developed to work in post-conflict societies ${ }^{2}$,the author adopted the EEA as it gives room for and voice to a whole variety of actors, practices and discourses visible in social movement situations. Issues such as poaching and substance abuse that have spawned off a variety of ideas and actions, situations conflicting action and. By laying equal importance on all the three nodal ethnographic aspects visible in social transformation- multiple actors, practices and discourses, it brings us closer to the aim of a sensitive and representational methodology. Specifically the adoption of this technique therefore necessitated the following plan of action in the field:

a) First, mapping the actors that cross the social movement paths. Practically speaking the strategy meant that as a researcher doing qualitative research, I needed to hang around the social spheres of multiple actors such as volunteers, activists or staff of a local social movement against poaching and opposing ones such as suspected poachers, commercial hunters as juxtaposed to those such as Bhils who possess a different world view than the above mentioned groups. My main research was an endeavor to investigate the transforming realms of social movement imagination and practices which, emerge, evolve from as well as merge, within the socio-political situations on ground. But my interactions with Bhils became the fermenting ground of an organic and holistic approach to the whole issue as opposed to adopting a mainstream, macro, universal perspective. Behind the veil of dominant one-sided assumptions, exist layers of everyday social action. Therefore the EEA entailed mapping the chief articulators (for my larger research, it meant the Bishnois)as much as those who were present as behind the scene endorsers and articulators. Equally important for my methodology was to work with those at the opposite end of the debate

\footnotetext{
${ }^{2}$ In its initial version, EEA was developed in 2007 for the research project on "Trust in Post-conflict Societies" by Gregor Dobler, Kerstin Bauer and Till Foerster at the Institute of social Anthropology at the University of Basel. Though it owed much to the methodology of the preceding project on Visual Culture in Urban Africa. It was later applied to several other projects, in particular to "The Work of State Imageries" and to a comparative project on the public sphere in Johannesburg and Maputo. For more details see, Förster, T. and Heer, B; Engeler, M; Kaufmann, AA; Bauer, K; Heitz, K. et.al. (2011).
} 
such as Bhils and discern their worldview, discourses and practices which silently fill up social movement space and time on ground. It is my work with the Bhils mainly that I highlight in this paper.

b) This brings us to the second implication of the EEA- social discourse analysis. From within the emic evaluation perspective, discourse offers a partial but precisely focused access to social reality. Again, standard procedures in the social sciences were applied, i.e. this step retraces relationships between social actors by examining what they say about each other and how they react to such articulations. Unlike Foucauldian discourse analysis, however, the EEA does not aim at the general structures of discourse where the actors just occupy a particular position without having much agency of their own. On the contrary, the EEA aims at the opposite: it assumes that the actors have agency and that their relationship to discursive formations is dialectical; they are shaped by them while simultaneously shaping them. Like in final version of the EEA, social discourse in my qualitative data, is not merely limited to verbal utterances, it incorporates all possible signs and symbols through which the actors actually interact and connect with each other.

c) The next in the circular chain of steps for me to follow in the field, was practice analysis. As pioneered by Max Gluckman and later refined by scholars of the Manchester School (e.g. from Epstein 1967 to Evens/Handelman 2006). It meant to follow the involved social actors (as identified in step one) and analyses how they engage in social practice and what consequences events have on how they interact. After having identified relevant practices for the thematic field of study, they were contrast with the outcome of step two, i.e. social discourse analysis. The aim was to clarify the relation between cultural assumptions and persuasions as they become visible in the discursive formation on the one hand and social practice on the other. Assuming that both will reshape how social actors identify each other, one would then contrast the findings again with the initial mapping of social actors - bring the circular procedure back to the start.

By adopting the EEA, my aim was to understand not only the Bhil posture towards hunting but also howit develops and gets developed by the actors in the vicinity andthe surrounding discourses through moments of silence as much as voice. Secondly, the EEA helped me place the actor- a subject for our analysis- as an autonomous (though embedded) part of a lived social reality and meanings from within his life world. In the analysis that followstherefore, I will focus not only on the language and speech of social actors but also the apresentation manifest behind beliefs and ideas in terms of past experiences and imagined futures alongside an awareness of that which is present and happening and open to change and interpretation.To sum up, the EEA is undertaken here by keeping in mind a post-structural approach where the universal discourse of power and knowledge in any given system is important not because it exists as a super imposed and 
fixed given but because the actor is seen as the agency which creatively dialogues this given and can act independently of it.

\section{Part II Bhils of "Shounkho Gaanv": "We cannot use the forest, we cannot use the $\underline{\text { state" }}$}

Bhils: The Bhils are one of the major Adivasi groups of western and central India. Consisting of multiple sub-groups such as Bhilalas, Barelas, and Naiks, the Bhils inhabit the largely hilly regions of northeastern Maharashtra, eastern Gujarat, southern Rajasthan and western Madhya Pradesh. In this paper, I shall use the term Bhil to refer to Bhils settled at the outskirts of Jodhpur. The term Adivasi, literally means "first inhabitant," and was coined by tribal rights activists early in the twentieth century to express their claim to being the indigenous people of India. The Indian government does not recognise Adivasis as being indigenous people, but defines Adivasi communities as belonging to the category of Scheduled Tribes as per the Fifth and Sixth Schedules of the Indian constitution Adivasis (Nilsen,2015: pp592-594). The Fifth and Sixth Schedules (schedules are basically lists in the Constitution that categorise and tabulate bureaucratic activity and policy of the Government) provide an array of protective legislation, special entitlements and reservations for Adivasis (Constitution of India).As per the 2001 census, the Scheduled Tribe (ST) population of Rajasthan State is $7,097,706$ constituting 8.4 percent of the total ST population of India. The Scheduled Tribes of the State constitute 12.6 percent of the total population $(56,507,188)$ of the State. The Scheduled Tribes of Rajasthan are overwhelmingly rural as 94.6 per cent of them inhabit in rural areas whereas 76.6 per cent of the total population of the state live in villages. Out of twelve (12) tribes scheduled for the State, Mina is the most populous tribe, having a population of $3,799,971$ constituting 53.5 per cent of the total ST population followed by Bhil $(2,805,948)^{3}$.

A striking feature of Rajasthan is the continuing close relationship of people and their habitat. Many communities still hold on their territories in spite of instances of small scale migration. This is remarkable because Rajasthan is one area which at least for a thousand years has been in a state of turmoil. Migrations from North to South occurred of the Rajputs and allied communities and also from West to East of many other communities. The degradation of the Aravali eco-system has had the most disastrous impact on the economy of marginal communities, even so there is no marked incidence of large scale migration, according to the present state of information. For at least two hundred years many communities have maintained their well-defined ethnic and territorial boundaries,(Singh, 1998, Foreword XVII). The hunting tribes as Bhils have traditionally been employed by the

\footnotetext{
${ }^{3}$ Census of India (2001). Rajasthan, Data Highlights: The Scheduled Tribe.
} 
upper castes- the Rajputs for instance, who were the historical rulers and then followed by the Mughals, both of whom recruited the artful adivasis in their armies. Even through the British rule and later in independent India the hunting communities have been relied upon for bringing fresh meat from the forest as one of the areas of historical collaboration between the rulers and the ruled, between forest and the non-forest communities or between local 'experts' of the forests and the powerful 'inexperts' from the non-forest backgrounds.

In order to fathom the complexity of this mutual, working relation between the forest communities and the non-forest communities, a little deviation into its historicity would be worthwhile here.

Skaria (1998, p. 208) thus suggests that the relationship between Bhil forest polities and Hindu tributary states were structured as a form of "shared sovereignty." Bhil chiefdoms were in fact "deeply integrated into the political economy of medieval India" (Guha 1999, p. 121). The terms of Bhil integration into the tributary states in the region were expressed in the fact that Bhil chieftains would make claims to dues - known as haks or giras haks - from peasant villages in the plains (Skaria 1999). These claims were recognised as legitimate by Rajput and Maratha rulers, and in those cases when Bhils descended upon the plains to raid, this was interpreted by these rulers as a sign that it would be necessary to renegotiate Bhil claims on the villages within their realm. Shared sovereignty, therefore, can be understood as a foundational principle of the structuring of political power in tributary states (Nilsen, 2015). Tributary states were grounded on forms of surplus appropriation in which monarchical rulers were basically dependent in a network of aristocratic fief-holders and landlords. Consequently, they were also confronted with what Haldon $(\underline{1993}, 156)$ has referred to as

the tributary constraint" - that is, the centripetal dynamics animated by the ruling elites that actually appropriated surplus from the peasantry. Governing a tributary state therefore came to orbit around attempts to "manage the ebb and flow of this internal tension that was part and parcel of historical dynamics of all traditional agrarian, subject-peasant ... societies (Berktay 1991, p. 260).

The significance of this in terms of understanding state-society relations and subaltern politics in the Bhil heartland is the following: the coming of the Raj did not entail the emergence of a relationship between tribal autocthons and a state-making project where earlier there had been no such relationship. Rather, colonial rule introduced a new form of state-making that changed the terms of Bhil integration into the regional political economy of. Singh (1985) found some of the uprisings in Bhil areas to be typical of the tribal movements that emerged after 1920: these were movements that envisioned in the Freedom Movement an occasion to reclaim the rights and prerogatives of a bygone era: "Swaraj to them meant not only freedom from British rule.... Freedom to them meant restoration of agrarian and forest rights" (Singh 1985, p. 161). The various forms of organic politics, i.e, from compliance 
with a system of shared authorityto contestation and conflictual relations with the foreign rule are pasts that find ramifications in the current day Bhil political imagery of hope, expectations as well as disappointment with the modern Indian state.

To come back to the context of this research, I begin by describing some excerpts from my own work with the Bhils. Forty kilometers away from Jodhpur, lies a Bhil area known as the Shounkho Gaanv (Gaanv means village). I reached there accompanied and guided by Triloka Ram, a stone mason, who was himself related to the Shounkho village families. One of my key non-Bhil informants in Jodhpur had helped me get in touch with Kailash, the Bhil cook at the forest research institute where I was staying. I requested Kailash to put me in touch with people of his community especially those Bhils who live in the deep desert zones and continue to practice their traditional lifestyles by and large. After 'observing' me for a week and quizzing me about my research, Kailash finally relented and set up Triloka Ram who would be my Bhil informant for the rest of the week. He took me to the nearest village from the city, where hunting was still practiced as chief livelihood alongside other emerging occupations. Needless to say, Bhil men such as Kailash and Triloka Ram were more urbanized as they had migrated to the city to earn a better livelihood. Their extended familiesstill live in the desert jungles practising subsistence lifestyles.

When we finally reached the shounkho Gaanv after negotiating a dusty, desert road, the car stopped at the last point beyond which it was not possible to proceed with a big vehicle. Negotiating the remaining two kilometres climb upward, by foot, we reached the Bhil families living quietly on the sandy, rocky desert stretch. Enroute to the living abode of the Bhils, I noticed how the sand was laced with dry animal bones and skulls of various shapes and sizes. This indicated that the hunted or preyed animals ranged from deer, antelopes to cows. When I expressed curiosity at the, 'spread', Triloka Ram with a nonchalant shrug of his shoulder opined, 'must have been due to famine or starvation which are common occurrences in this hostile desert' - negating my conjecture that the images already indicated that we are among hunting communities. Later, the families that I met in the villageremained reluctant to speak much on the presence of the skulls and bones ${ }^{4}$. They did say, however,

\footnotetext{
${ }^{4}$ I faced the same reaction from the Ban Bawaris, another tribal community that I worked with in western Rajasthan. Aware of the changing state laws on hunting of endangered species amid the growing Bishnoi protest movements (Luthra Sinha, Forthcoming: 2015a) these communities refrain from public acknowledgment of hunting practices, owing to various complex factors. These include fear of legal punishment, or conflictual relations with Bihsnois living in proximity of their areas. At the same time, the continued clandestine hunting indicatesthe short sightedness of the rule of law, which has acquired an essentialist garb, setting one community against the other in its wake. (For details read, Luthra Sinha, Forthcoming: 2015)
} 
that sometimes their dogs ${ }^{5}$ that are fed with left-over meat and bones may carry their 'meals' a bit far from the Bhil huts. And, hence the scattered bones. Other actors such as the conservationist Bishnois, among whom I conducted field work in Bikaner and Jodhpur,opined that the bones were an evidence of the hunting practices of the Bhils. Scattered bones also indicates, they confirmed, that leftover meat is fed to the Bhil pet dogs, that carry off and enjoy the meal a bit far away.

I decided that for me as a researcher, the implications of the two conflicting positions, juxtaposed to each other were far more helpful as they were able to represent the evolving organic relations in the region, than the actuality of the 'truth' or 'lie' exposed by the presence of the bones. It is however, interesting to note that in the Bishnoi regions, where I carried my research, no animal bone was ever spotted by me.

Gokul Ram (Interview 12 December, 2013), a lean old man from 'Shounkho'- the Bhil village forty kilometers away from Jodhpur, informed me that he had no background in formal education. He recalled his age as being, "approximately between (Interview, December 13,2014$)$ sixty five to seventy five years. However he remembered very well that his family has been living in this place since the past thirty years. They were 18 family members living together. Looking much older than his stated age (because of his withered body), but firmly perching himself on a big stone inside his 'Bhil Compound' that consisted of a few scattered huts (Bhils live together in Pals- which appear to be an isolated series of scattered huts. (see, Singh, 2013: 58), he called his family over to speak with me. Possessing the proud demeanour of the head of the family, he informed me that he and his wife live with their three sons and their families together. Speaking with the weight of time, he talked about marriage rituals and how a Bhil wedding remains incomplete without serving mutton (goat meat).Whenever they gather for a 'dawat' (lunch/dinner party), the guests are accorded a customary welcome with non-vegetarian delicacies. On a daily basis, however they drink tea to start their day as the milk that they can manage with their petty sheep herd is neither enough for drinking nor for making Ghee (Indian clarified butter).

Kiran, Gokul's more vocal, thirty five year old daughter-in-law informed me (Interview, December 13, 2013) that her husband, Mala Ram was forty years old and their eldest son had just become twenty one. As far as their livelihood was concerned, it was a mixture of professions- the old and the new. They liked rearing goats and sheep and also sell them as per demand. They also hunt when required. But they also need money to buy vegetables (preferred ones- chillies, onions, potatoes and tomatoes), sugar( half a Kilogram is used each day in making the morning tea for the family), grains from the market regularly. Money which has become an important requirement comes in on the side through other professions

\footnotetext{
${ }^{5}$ Bhils have a special attachment to dogs. They keep them as valuable pets and have certain beliefs and rituals around the creatures. (see Singh, 2013, p. 56).
} 
that their men have adopted such as becoming stone masons. But they only bring home a meagre income. As Kiran pointed out, "the employers pay them very little." Kiran conversed freely of their hunting and meat eating rituals. They like to hunt small creatures such as rabbits which were easliy available without controversy. She elaborated,

"We liked eating deer too. 'Lekin ab Hiran marne par zamanat nahi hoti' (But now upon hunting deer, one does not get bail) ". We also come to hear incidents how other tribes such as the Kal Beliya become involved in debates with the system as well as others against hunting. One called, Jogi, from the kal Beliya community was jailed in a village, ten kilometres from here. Earlier this community was not settled but now like us they are more or less practicing settled lives- which has its own downsides. If we hunt, for daily consumption, taste or for a ritual such as use of particular meat during marriage ceremonies, we are more easily spotted because everybody knows where to find us! We therefore avoid any controversial meat. Now that we are more aware of how the meaning of hunting has changed in legal parlance and how other communities now wage anti-poaching movements ${ }^{6}$, we too see it differently now. But 'we' have not made the species 'endangered' $"$.

Political Imagery of the Bhils: At this point, Jamuna (Interview, December 2013), Kiran's mother-in-law joined in and spoke from behind her transparent veil just like her daughter-in-law had been doing. Jamuna spoke shyly at first, saying that the deer is an example of meat which they liked hunting for themselves. But they also search out smaller animals and reptiles for other uses. For instance, a particular variety of a desert lizzard is used to make a therapeutic soup for their camels. This soup is fed to their camels since times immemorial as it is known to be beneficial for imparting it a muscular strength and agility for running in the desert. Suddenly, her political imagery took the better of her, she lost her composure and made a sarcastic comment, which touches upon the idea of 'visibility' and 'invisibility' in modern state systems,

"We are so much condemned for our hunting practices for we become 'visible' to the system when we hunt! When we need running water and electricity no one sees us (!). Our houses in this Shounkho Gaanv (village)....haves no power or running water supply. We are fed up of waiting. We have installed a hand pump to fulfil our needs. We live in one place now and need those resources. We regularly vote for the congress. But when the government fund comes, it goes to the village headman who is of the 'Mali Jaati' (gardener caste). We seldom get any share of these development funds. Bhils are further marginalized because they lag behind in education and are most of the times illiterate. Bhils do not have

${ }^{6}$ For details on the Bishnoi anti-poaching movement, see, Luthra Sinha: 2016 and 2015 (Forthcoming) 
representatives in positions of power such as in administrative jobs where the educated people of other castes establish domains- Meena caste for instance are educated and become 'collectors' (this is a coveted administrative position and is almost used as an indicate reference point to judge the holder's access to power within the Indian state). We Bhils, on the contrary have remained very poor. So, we cannot use the forest and we cannot use the state."

I remained very quiet and pensive. But the mother-in-law and daughter-in-law duo after having expressing their grudges against the system and their situation, surprised me with cathartic smiles, flashing their bright teeth from behind their red veils. Suddenly the patriarch asked the womenfolk to make tea for me. As we sipped our sugary teas made of fresh goat milk from their compound, I teased the women about their lovely red 'veil' and asked them if they would show me their faces. They relented shyly and broke into peels of laughter as we stared each other face to face. But made a special plea: I would try and use only those photographs where they appear with the veil, preferably!

Taking me inside their houses they showed me their small kitchen and their rooms. I noticed the low roof of each hut was like a mini-museum- for on it hung securely, meticulously every item of interest that caught the Bhil fancy- sticks, dried fruits, bones, rags, mirror pieces, bird-feathers, horns and grass. The women told me that they liked decorating their roof thus. It was as if the Bhils had carried a bit of their sacred desert inside with them to give it an eternal hug- to stare at all the objects strewn in its womb and take them along into their dream worlds, when they lie down each evening. The sweet warmth and the comfort of the Bhil roof turned into a red, hot, peppery fire as Kiran signalled me out towards her open kitchen to show me another sacred activity: The making of the famous Bhil red chilly paste on the Sil-Batta (stone crusher). Her deft movements merged the suspended, distant space and time into the ongoing Bhil moments and imparted a distinct flavour into the potently delicious Indian Chutney (spicy salsa) to be eaten with fresh Rotis (wheat breads).

No less spicy than the famed red Chutney, are those parts of the prejudiced and essentialist descriptions found in 'official' sources that are symbols of a historical canon against these strong survivors of terrain. As per historical records, Bhils are a pre-Aryan race. In the 1891 Census of Marwar, Bhils out-numbered all the other Forest and Hill Tribes. They are found in almost all the districts of Rajasthan and especially abound in the villages bordering the hilly tracts and jungles. According to Col. Tod, "the earliest people that inhabited 'Mewar' "(as Rajasthan was called earlier), (Singh, 2013, p. 57). There are traces of Bhils before the advance of the Aryans in the Deccan. In words of Dr. Hunter, "when they cannot get grain, they feed on wild roots and fruits, on several kinds of vermin, on animals that have died a natural death and probably in remote places on the flesh of a cow" (Singh, 2013: 60). The 1891 census states, "though Bhils were formerly inveterate thieves and 
robbers, they are now losing that character possessing about hundred and fifty thousand bhigas $^{7}$ of land. They act also as shikaris (hunters), messengers and general servants. They also cut and sell grass, manufacture baskets and in some villages they act as 'Dhuniyas' or cotton cleaners" (Singh, 2013: 60). Of special significance is the fact that most of these descriptions, while accurate, also reflect the social stereotypes in the Indian society.

The 1891 census remains an important document for understanding the changed practices of the various castes as well as the castes themselves. However it does well to remember that this particular survey was undertaken with the motive of making the Indian castes comprehensible for British administrative ease and rule (refer to Singh, 2013: Introduction by Kothari). Therefore the descriptions and statements available in the 1891 Census, besides giving data and descriptions on Indian castes of the time also mirrors as much as it fosters social stereotypes of that period in its. Also it was the first time that there was an exhaustive enumeration of castes in Marwar region and of Rajasthan under one work. Initially, relations between the Bhils and the British did not differ from those between the Bhils and the Marathas' kings: they were all marked by a continuous process of compromises, achieved with the help either of bribes ${ }^{8}$ or of war and threats (Guha, 1999, p. 130). Others opine

However, later in the century, the Bhils were witness to the 'deconstruction of a system of political relations between the polities of the forest and the open country that had existed for centuries past' (Guha, 1999, p. 135). This was due to fact that the British began to amend laws in ways that created 'social bandits and rebels out of peasant protesters and men of political ambition' (Guha, 1999, p. 134) One witness of the period wrote: "Outlaw Bhils, like wild animals, require a large extent of jungle in which to hide and from which to sally forth" (Guha, 1999, p. 137) ${ }^{9}$. Notably, many official reports by administrative officers describe the native landlords that they were dealing as 'grown-up children' or, even worse, as 'idiots'. This attitude was reflected in the kinds of policies that followed. The main aspiration was to deprive the Bhils of their forests in order to 'clean' the country, to make the 'forest folk' settle, and to make peasants out of criminals(as they were regarded at that time). For that purpose especially, the Forest Department was created, gradually taking power and

\footnotetext{
${ }^{7}$ Bhils enjoyed various kinds of interaction- from serving in the army to The Bhils conducted raids to collect goods and cattle from the nearest villages, and the native kings tried to put an end to such disastrous activity; as a result, skirmishes between them were not rare. However, sometimes the kings chose another tactic: in order to stop the Bhils from plundering their lands, they gave them money, or luxury goods, which the Bhils either enjoyed themselves or used in trade. The Bhils were also known for their martial skills and were widely employed in different military roles. For instance, when going to war, kings would recruit the Bhils into their armies. At other times, these 'forest people' were employe At other times, these 'forest people' were employed as crop watchers, wood-cutters, and hunters (Guha, 1999, p. 112). Because they took part in the economic activities of the region and knew how to take advantage of political tensions in the region, their culture had a significant influence on the whole area. 9
} 
authority from the Bhil chiefs and marginalising their communities (Guha, 1999, p. 140). The policy did not take into consideration the self-perception of the Bhils as warriors, not peasants, nor that they viewed the forest as their home. Hardiman $(1987$, p. 9) argues that even the role of "tribals" in "making of their own history is correspondingly ignored" (Grinko, 2014, p. 6$)^{10}$.

My study argues that to explore the nature of Bhil posturing in the ecology and conservation debates, one needs to sift as much through their instances of voice as through their practices of silence over the issue. For this end, we would need to learn newer forms of ethnographic descriptions beyond the archaic and jargonistic caste- tribe mode of analysis alone. Social spaces of conservation and ecology, with their window of unpredictable and fuzzy transformations stimulate us to think away from the iron shackles of stereotypes.

Historicity,Talents and Metaphors: One way to understand the Bhil in contemporary space and time would be to examine their position of silence (of negating 'hunting') in light of Bishnoi social action against poaching in western Rajasthan. Mahipal Bishnoi, a lawyer from Jodhpur, volunteers for Bishnoi activists by contributing his know-how to the anti-poaching efforts. He advises the activists over legal issues and aspects of pending or ongoing court cases. However, M. Bishnoi points out that during his long time tryst with poaching cases and after examining various versions of those who are explicitly commercial and those who belong to communities like the Bhils, he has learned much. In his view many petty poaching crimes reported as emanating from the forest communities have another side to them: The forest communities remain tempted follow their own practices because their lives and struggles have been slow-pedalled and ignored by the government(Interview, December 17, 2013). He elaborates,

"The elites make use of the Bhil marginalization and 'groom' the community's monetary dependance into lucrative business offers involving supply of exotic meat- which in western Rajasthani context is mostly venison. The Bhils can hunt the black bucks or chinkaras (Indian Gazelle) swiftly. There is a well-knownsaying that, left to its own recourses, even a young Bhil child can run as fast as an antelope in the forest- The Bhil kids are trained to do so. For the forest and its creatures are a form of play, a means to pass on knowledge and a ground to test evolving skills, all combined. It is a didactic package, an inherited talent and an associative relationship between man and nature, whereby ritualistic abilities are honed and tested in the backdrop of the forest and its wildlife. One cannot grudge a community its natural talents or preferences- but unfortunately the turn of circumstances is such that precisely these very characteristics have come in the grip of

\footnotetext{
${ }^{10}$ For a socio-political debate on terms and conditions for knowing, understanding the term tribe or adivasis (indigenous peoples) in general and understanding these wrt Bhil identity in India, see Grinko (2014); Jain (1991); Chaterjee (2004 and 2008).
} 
controversy. The problem is however not describable in simple black and white. Much work needs to be done on either side of the issue. The Bishnoi activists are therefore in search of adequate solutions."

Another way to explore Bhil self-gaze is analysing their voices to reach the imagery visible in their metaphoric accounts: For instance, Two Bhil characters etched upon the popular imagination relate to important side stories within the two great Indian epics of the Ramayan and Mahabharat written thousands of years ago. The characters of Bhilni-the old, humble Bhil woman-devotee and her ecstatic culinary welcome accorded to and accepted by an Indian diety as well as Eklavya, the young, skillful archer boy from the Bhil community whose skills are disrespectfully crushed by an upper caste 'Guru' (Master- trainer in this context) feature in popular stories, drama as well as religious discourses. During my field work I observed that not only do these two names still become a reference point for talking of the Bhils and understanding their lifestyles, the community itself does not fail to talk of Bhilni and Eklavya with pride and pain.

In reference to the Bhil contribution to the discursive formation on hunting this gesture can be interpreted in three ways in reference to the: First, as, proud mode of introduction used by the Bhils (for the benefit of the outsiders-like a wandering researcher) as much as for giving vent to their need for an acknowledgement of their historical presence since times immemorial. Second, to perpetuate folk memory (for the insiders- their children etc.) for internal consumption. Third, it becomes a subtly powerful comment to the condescending way that the mainstream castes have 'included' or 'excluded' the Bhils in everyday life. But to be fair to the processes of evolution, life has moved on for them beyond these popular images and conceptions and other modes of inclusion and exclusion have been added to the already existing casteist gaze- such as, the Indian job reservation system which has created a highly debatable and politicized division of resources.

c)Motorbykes, Markets and Reverse Integration: Receiving education, enjoying infra-structural facilities or gaining an access to the promised pie seems too forlorn a possibility. Perhaps this is the reason why they continue to make do mostly with, what the world considers as 'bare minimum essentials'- of food, clothing and shelter; but they have worked out ways to compensate themselves by enjoying the gains that their talent can help them negotiate in the same system that denies them. The Young Bhil man named, Sohanram, who volunteered to escort us back to our car safely as it was becoming dark surprised me by trailing along with me on his motorbyke. In the conversation that ensued between us, he explained how attached he was to the two wheeled delight in his life because it links him to the world outside. Besides it is faster any more convenient than the bicycle and give that cars cannot be used on the hilly terrain where he resided, the byke was 
his family's perfect possession. He accomplished many errands for his family by bringing food and vegetables up with it. When I asked if the vehicle was a burden on his pocket, Sohanram smilingly replied, "Not at all. These days we get loans for buying motorbikes easily and in conformable instalments. So we do not have to hurry or worry over returning the amount."

As Sohanram escorted us down the rocky path, he whistled to a passing shepherd boy who was busy tending his herd of sheep, with his humble companion- the Lathi (stick). They wanted me to click and I used the camera one last time in Shounkho Gaanvi. Village: Picture attached above). His motorbike was a symbolic indicator of how the family's political dreams and methodologies are changing. My interviewee, the Bhil youth, makes it clear that the motorbykehas become a part and parcel of his life. It has multiplied his family's access as well as dependence on further consumer durables. The market is closer and more accurate in identifying their needs and patterns of consumption than the state, its sluggish distributive justice or its narrow rule of law ecology. Meanwhile, theabsence of access to water and electricity is not forgotten by the Bhils. It remains a burning issue and adominant part of their political imagery. Simultaneously newer modes of associating with the market and technology have changed the ways that the Bhils practice economy and would definitely usher in many other kinds of integrated needs and awareness. For instance, cell phones are one such device whose utility has captured their fancy. Today commodities such as motorbykes and cell phones are an aid in the life of forest communities, unlike before. In turn the market is busy recognising them as potential customers and clients.

\section{Part III Caste and the Shifting political ecology of Western Rajasthan: Changing cateogaries of Practice}

a) Caste: Per se, an analysis of caste as a social cateogary is beyond the purview of this research. However we cannot deny that stereotyping plays a definite a part in many kinds of casteist practices and imaginations just as it did before. Of course, the overall context has undergone a sea change. Kothari states (Singh, 2014, Introduction) that 1857 revolt onward, the whole atmosphere under which caste had been discussed got transformed. Caste had now an immediate bearing on the formulation of government policyon which was contingent the destruction or continuation of the British Raj. It is from this perspective that one must view the early Census Surveys as well as the proliferation of literature on caste. Most of the officially recorded information on castes and communities in Rajasthan became exhaustively available for the first time in the 1891 census report. However, in those times, alongside an enumerative function, the Census also enlisted social stereotypes quoted in words of foreign scholars, explorers, missionaries, traders, 
administrators and officials. Accordingly if one was to judge Munshi Hardayal Singh's classification of castes and sub-castes of Marwar towards the end of the nineteenth century, as Kothari opines (Singh, 2013: See Introduction), it reveals a number of inadequacies and anomalies. But it permits us to have an idea of the then prevalent cateogories employed to understand castes and reveals several vital aspects of Marwari society. But it is also problematic as it functions like a double edged sword. While it points to the social imagery of the times in an etic analysis rich in historical facts, it also gives away a certain confidence in presenting and perpetuating negative stereotypes 'convincingly' by quoting extensively from colonial sources.

At the turn of the twentieth century, India witnessed another spurt in caste based analysis owing to the emergence of Anthropology as an independent discipline. Caste as a type of social stratification did not fail to raise the curiosity of this second wave of narratives. Usually in such studies caste descriptions mainly revolved around three salient features: the mythical origins of the caste in question, marriage rules concerning the caste and death ceremonies (which reveal succession rites etc. ). By independence the articulation on caste underwent another radical change and posturing. The Indian Constitution does not recognize the social stratification implicit in the caste system. Kothari states,

It is only in the form of scheduled castes and scheduled tribe that some sort of caste element made its way in the Constitution. Accordingly, the first census of independent India in 1951 was conducted without any reference to caste. No longer did social description or ethnographic evolution form a part of the census results (Singh, 2013, p. iv).

The most natural question to ask here is to what extent has this approach helped to reduce social antagonisms? if the policy of the British Raj towards the caste question, formulated with a view to safeguarding the continuity of British rule, resulted in livening up the caste spirit and providing incentive for the consolidation of caste groups, the postindependence democratic process, despite its avowed intention of building a cohesive national society, has also contributed to the accentuation of the caste antagonisms and the solidifying of caste identities (Singh, 2013 : Introduction xii) . But for our research the more vital question to put is - "does silencing of the caste aspect help in understanding the social protest context in western Rajasthan or is it an essential o understand caste-tribe equations to undertake a contextual analysis rooted in community time and space?" - Just as it is difficult for technology or development to resolve social maladies by itself without understanding agency behind social structures such as caste and tribes in India, the micro social movement context would remain partially legible if the complex imaginations around caste that inform and make up practices of inclusion, exclusion, solidarity and opposition around social action are left out. 
Neither the social movements of the Bishnois nor the positioning of the forest communities can be completely understood if one stops short at socio-political stereotypes. If instead, these practices on ground are read together with legal and administrative interventions of the state, they reveal an urgent grassroots dynamics- which not only influences the way communities interact with each other but it also provides us a newer window to look at ongoing transformations they negotiate. From that vantage point, one can began to understand the relationship between newer modes of positioning among communities in the region over newer issues.

\section{Part IV Concluding Interpretations:Organic Laws or Market Ecology?}

After showing how the communities continue to feel betrayed by statist requirements of a one-sided integration, this section takes the view that practicing of organic and inclusive laws may be an ideal solution. There could be two kinds of environmental concerns from which to further the forest and wildlife issues portrayed by the Bishnoi Social movementsthe global or the local. Although the media focuses a great deal on climate change and governmental policies too seem connected to such macro articulation and global concerns, Guha(2011)suggests, we should in fact be more concerned about the sustainable management of nature and natural resources within the country. "For India," as he says, "is an environmental basket case in at least five respects:(1) The rapid depletion of groundwater aquifers; (2) the impending or actual death of our major rivers through household sewage and industrial effluents;(3) the excessively high rates of air pollution of our cities; (4) the unregulated disposal of chemical and toxic waste; (5) the continuing degradation of our forests and the associated loss of bio-diversity ${ }^{11}$. These problems have local, regional and national impacts. Collectively considered, they raise a huge question against the sustainability of present patterns of agrarian and industrial developments".

Guha (2011) goes on to analyse that we must therefore become more pro-active on the environment in our own national interest, and regardless of our global obligations. It is

\footnotetext{
${ }^{11}$ Studies show how the desert and semi-arid areas have witnessed increase in human density due to the development of Indira Gandhi Nahar Project and resulted in large scale ecological changes. Traditional crops are being replaced by cash crops which require more irrigation. An intricate network of canals has raised the humidity levels and converted large tracts of desert to cultivation. Misuse of water facilities has resulted in water logging and increased salinity along the length of the canal.... The changed habitats---seepage, water, cash crops, wetlands). Habitat alteration by expansion of agriculture or by human settlements, developments of roads or canals, spread of industries is still going on and unless immediate steps are taken there will be conservation disasters. In addition to unsustainable development pressures, hunting, mining, oil exploration, increasing human population...all geared for habitat disaster of various species in the desert. (Sharma, Kulshreshta and Rahman, 2011, pp 340-357).
} 
not enough to stop destructive practices (such as mining in tropical forests); rather, the Ministry of Environment must nudge other Ministries and society at large towards more sustainable forms of resource use. The Ministry must take the lead in framing suitable policies in different resource sectors. At the same time, individuals and communities also must take greater responsibility for the consequences of their actions. Here it is apt to point out how beneficial collective social action can be. For, as we see in the previous section of this chapter, the BSM activism (See, Luthra Sinha: 2016 and 2015), by bringing multiple actors and world views into context, serves to galvanize and dovetail the whole issue organically- just in the way radical specialists, intellectuals and concerned authorities have been asking of us.

The environmental crisis in India is many-sided and multi-faceted. It has to be addressed on different fronts and by a variety of different actors. We need to harness scientific and social-scientific expertise to develop and promote eco-friendly technologies in energy, water management, housing, and transportation (among other fields,) scientific innovation needs to be complemented by legislative change as well as by changes in social behaviour. For this, we need new ideas, new innovations, new institutions, and, perhaps above all, a more imaginative and less short-sighted political leadership (See Guha, 2011). The value of evaluating the emic context of BSMs is that first we see how multiple, conflictual positions become synchronized with each other and second they bring forward ways of participatory solutions to ecological crisis. Third, collective social action of theBishnoisjuxtaposed to the world-view of their adjacent communities such as Bhils lays threadbare the discrepancies in the ways in which environmental legislationapplies to as well as unfolds on the ground. The BSMs, do not rally around the issue of environment in a global context, rather they render their expertise and valuable social work to the cause of protecting local wildlife and vegetation first.

Similarly, the Bhilswith their acts of resistance against the prohibition of hunting clearly portray a positional disagreement with coffee table policies of the state. They point to the need of innovative approaches for bringing in just considerations of an organic and inclusive ecology over and above a socially exclusive conservationist ecology. Effectively the contesting position ofthe various actors indicate that, poaching as an environmental crime, requires to be urgently re-visited. The purpose of such an action should be to judge commercial environmental crimes separately from those cases wherein the livelihood and customary needs of meat eating forest communities in western Rajasthan come into 
question or there is an information gap between state and communities ${ }^{12}$. Further, although there are legal remedies such as differential slabs of punishment depending upon the frequency of crime or the schedule of the animal (as explained above), there is a need to extricate the patterns behind different kinds of environmental crime and records of punishments given to see how justice is being actually delivered on ground. If such a knowledge base is created it would help ascertain the percentage of damage done by each kind of environmental crime and state response to it. It is pertinent that the odd situation created by the conflicts created between of the rule of law, hunting practices, poaching and environmental crimes in Western Rajasthan must be dovetailed by updating the ideas behind state conservation efforts to suit the local needs and produce locally relevant science.

The Bishnoi contestations against poaching have generated valuable social data in the direction of collaboration between their own ecological orientations, knowledge of forest departments and police by working together to prevent the loss of injured and sick wildlife or initiating judicial action against poachers. Simultaneously, understanding the alternate ways other communities engage with wildlife and their exact reasons for continued abeyance of hunting laws can fill an information vacuum successfully. A purely legalistic view which divides the field between crime and punishment may not suffice to link up gaps. .Some uses of wildlife are medicinal and curative and come in handy for communities who are not integrated in the modern state or medicine system and hence rely totally on their own recourses(Jain:2007) in her study argues for the protection of fast depleting ethno medicinal knowledge of various communities. Hence there has to be a mid-way approach between scientific conservation of nature and conservation of traditional systems of knowledge: These two processes cannot be seen as either/or because none exist in a vacuum bereft of one another. Even if the state has not integrated the hunting communities or these continue to live in isolation, the state owes protection to their value systems and cultures by the same coin as they owe obedience to its rule of law.

If environmental crime is to be recognized as crime by the communities in the first place and prevented as such in the name of conservation, the forest communities have to be taken into empathetic confidence. The hindrances in lifestyle that communities undergo as

\footnotetext{
${ }^{12}$ Because of Wildlife protection act 1972, hunting of wild animals are strictly prohibited but sometimes local religious norms is superseded especially in case of saving life or in other hazardous situation. In such circumstances communities dare to hunt even the national bird, the peacock. (Jain, 2007).Ban Bawris in western Rajasthan are known too consume Peacock meat/organs for various ritualistic and curative purposes, as narrated to me during field work by various stakeholders in the Bishnoi Social movements.
} 
an outcome of prohibitory laws need to be understood in a more organic (closer to the everyday life) way. This is an issue which definitely adds to the validity of debates on, as Guha and Gadgil call, 'India's fissured ecology'. In India the people oriented environmental debates have taken an altogether different track from their western counterparts. Western environmentalists, contemplating the arrival of the 'post-industrial' economy show more inclinations towards a 'post-materialist' perspective in which the forest is not central to economic production but rather to the enhancement of 'quality of life'. In India, by contrast, the environment debate around the forest and the environment more generally, is firmly rooted in questions of production and use (see Guha and Gadgil,1992, p. 245).

Inadvertently, Bishnoi movements and the discursive ecology fuelled by them reflect the peoples' growing sense of engagement with the question of nature: First and foremost the movements raise a direct stake in caring for the environment. The second direct significance of BSMs is that it brings to light how local communities exercise their agency by claiming participation in joint resource management. Bishnoi activism towards saving the endangered species through the joint force of older (cultural knowledge, customary skills) as well as newer modes protection (awareness of legal provisions, establishment of rescue centres, peaceful and collective protest marches etc.) is path-breaking. Once again,it proves that a purely western conservationist notion for communities and locals to keep off environment' cannot become suitably workable or legitimate in India. Third, the Bishnoi protest movements point our attention, indirectly, to the need to re-visit as well as differentiate between various environmental crimes for the sake of comprehending the grassroots need of Bhils more empatheticallyas well as for developing newer categories such as crimes for subsistence or crimes for profit. The discursive ecology that has come in place in Rajasthan begs the question of settling respective proprietary claims of individuals, communities, and the state in ways suitable to the Indian spaces and time.

Hence the need to encourage a parallel academic and specialist attention long due to this issue alongside a change in the mainstream policy makers' mind-set cannot be undermined: The onus of abandoning lifestyles and adopting transitioning choices and perceptions in accordance with the changing policy times and spaces, must not squarely rest on the shoulders of the marginalized communities such as the forest peoples alone. Communities who live in remote forest areas, such as in the arid forest zones of western Rajasthan and face displacement of their socio-economic and cultural characteristic's loose many kinds of resources simultaneously. Aside from facing vulnerabilities in socio-political hierarchies, they may lose out as have-nots in many other related spheres too- when pushed to the peripheries of their practiced lifestyles but denied a full access to resources 
useful in those contexts, they may lose out other possessions too. For instance, over the years medicinal folklore has proved to be important in screening of modern drugs (such as digitoxin, reserpine, ephedrine to name a few; for more details,seeAniyinam 1995). In this view, it is suggested that alongside the conservation of wildlife resources, what is needed to be dynamically conserved in accordance with changing times are valuable knowledge systems and practices attached to the dwindling wild.

It was more than three decades ago that a Department of Environment was set up in the Central Government and a few years later it was upgraded into the full-fledged Ministry of Environment and Forests (Khagram:2011) ${ }^{13}$. Even if the structural framework and vision of the state are in order, the systemic apathy that greets ecological imbroglios in western Rajasthan reveals a legal, moral and political bankruptcy, which is hard to overlook.Part of the problem is that these structures meant to regulate the balance between environment and development are Surrounded by an elitist, Sensex oriented imagination and engagement with 'development' ${ }^{14}$, the state engagement with peoples' ecology has been less than appropriate. Over the recent years this conventional wisdom has been challenged by scholars and activists who have field experience in different parts of the country. They make two central arguments (Guha, 2014):

First, that industrialization and economic growth in Europe and North America was enabled in part-perhaps large part-by the access to the land and resources of the colonies that those countries controlled. Developing countries like India have no such colonies; and they have far higher population densities. Therefore, they must in fact be even more environmentally conscious than Europe or North America were at a comparable stage

\footnotetext{
${ }^{13}$ Indira Gandhi's prime-ministership (1966-1977 and 1980-1984) introduced environmental debates into the national political agenda. The 4th Five-Year Plan (1969-74), for example, proclaimed "harmonious development [...] on the basis of a comprehensive appraisal of environmental issues." In 1976 (during the Emergency) Gandhi added Article 48A to the constitution stating that: "The State shall endeavour to protect and improve the environment and to safeguard the forests and wildlife of the country." The same decree transferred wildlife and forests from state list to concurrent list of the constitution, thus giving the central government the power to overrule state decisions on that matter. Such political and constitutional changes prepared the groundwork for the creation of a federal Department of Environment in 1980, turned into the Ministry of Environment and Forests in 1985.

${ }^{14}$ In her recent book Green Wars, the environmental journalist Bahar Dutt writes: 'The editor of a leading media house, everytime I pitched a green story, would invariably complain: "Environmentalism is stalling growth; all I am interested in is double-digit growth for this country". Guha elaborates that the idea that environmental protection and economic progress are at odds is widely held among India's 'development' oriented elite. It is shared by newspaper editors, economists, businessmen, and, not least, politicians. The free-market thinker Gurcharan Das has written with disdain about what he calls 'the fundamentalist and irrationalist nature of the ecology movement'. While he was Minister for Civil Aviation, Praful Patel insisted that 'in a developing country, environment standards laid down by developed countries can't be taken as the thumb rule.' This was in response to a question about the environmental damage that a proposed new airport in Mumbai would cause. (See, Guha, 2014).
} 
of their development experience.The second argument focuses on the social consequences of unregulated economic growth. For, in countries like India, as my case study shows, it is the subsistence communities and the poor who most directly bear the burden of environmental degradation. Depleting forests deprive peasants of fuel and fodder. Polluted rivers deprive them of irrigation water (and sometimes of drinking water too). Open-cast mining brings debris to fields and dries up springs. Meanwhile, in the cities, air pollution makes the urban poor-badly housed, over-worked, and under-nourished-more vulnerable to respiratory and other diseases than their richer (and better-fed, better-protected) counterparts.

These two arguments were first made in the 1970s, by popular movements such as the ChipkoAndolan, by scientists such as MadhavGadgil (of the Centre for Ecological Sciences in Bangalore), and by campaigning journalists such as the late Anil Agarwal (of the Centre for Science and Environment in New Delhi). The combined efforts of activists and scientists led to the formation, in 1980, of a Department of Environment and Forests at the Centre, upgraded to a full-fledged Ministry five years later. The Environment Ministry was meant to be a regulatory as well as a prescriptive body. On the one hand, it had to frame laws to check environmental damage, monitor air and water pollution, and assess the environmental impact of proposed new mines, highways, dams, and factories. On the other hand, it was meant to fund scientific research so as to forge sustainable policies for forestry, wildlife, agriculture, energy management, etc. Regrettably, for much-if not most-of its existence, the Environment Ministry has not fulfilled either objective,(Guha, 2014) optimally.

In face of the changing legal perceptions on hunting and depleting environmental resources, the relationship between communities on ground has also registered a newer politics. The many questions that arise with respect to the BSM and politics of huntingpoaching are as follows: Did the government of India understand that the traditional hunting communities needed to be genuinely informed, consulted and if not taken into confidence, at least taken into consideration before announcing laws affecting their practices directly? Or is to be assumed that after bouts of an indigenous shared sovereignty followed by a contested colonial one, Bhils have to reckon with a one sided version of statist power where room for dialogue with regards to hunting practices and rule of law stands closed? Even if a borrowed conservation ethic is to govern India, are sustainable hunting needs of local communities such as Bhils not different from those portrayed by vested commercial interests? If the law makers were serious about the laws they have announced, one is tempted to ask, how well 
did they consider the fact that the field is fraught with a complex social dialectics, inherited castes, tribes and political power ${ }^{15}$

However, as things stand today, the state seems to have lost credibility and trust among those Bhils who practice subsistence lifestyles. Unable to gain basic necessities from the state, such as the promised water and electricity, education and welfare, the Bhils are coming to terms with yet another of its failing. Through its rulings on wildlife protection, the state demonstrates once more, its scant respect for deciphering the socio- political impact of such laws on grassroots inter-community dynamics. This aside, there is a lack of vision for rehabilitating the desert communities for their loss. Even as the friction between the state and the communities manifests steadily, market forces have stepped in dynamically to create a financial dynamic amidst the chasm.

\section{References}

Aniyinam C. (1995). Ecology and Ethnomedicine-Exploring links between current environmental crisis and indigenous medicinal practice. Social Science Medicine, 40 (3), 321-329.

Berktay, H. (1991). Three Empires and the Societies They Governed: Iran, India and the Ottoman Empire. Journal of Peasant Studies 18 (3-4), 242.

Chatterjee, P. (2008). Democracy and Economic Transformation in India. Economic and Political Weekly 43 (16), 53-62.

---.(2004). Politics of the Governed: Reflections on Popular Politics in Most of the World. New York: Columbia University Press.

Dutt, B.(2003). The forgotten People: Bawarias of Rajasthan. Proceedings of a public hearing. Draft. New Delhi.

Evens, T.M.S./Handelman, Don (Eds.) (2006).The Manchester School. Oxford: Bergham.

Epstein, A. L.. (1967). The Craft of Social Anthropology. London: Tavistock.

Förster T. and B. Heer, M. Engeler, Andrea A. Kaufmann, K. Bauer, K.Heitz et.al. (2011).

The Emic Evaluation Approach -- Epistemologies, Experience, and Ethnographic Practice. Basel Papers on Political Transformations. September 2011. Institute of

Social Anthropology, University of Basel. Retrieved from http://edoc.unibas.ch/23547/1/Basel_Papers_No_3.pdf. (March 7, 2015).

Grinko, E.(2014). In light of the experience of the Bhils, what does it mean to be 'tribal'?, South Asianist, 3, 256-266. [See also, The Imperial Gazetteer of India (1908, p. 101)].

Gadgil, M. and Guha, R. (1992). This Fissured Land: An Ecological History of India.California: University of California Press and OUP.

\footnotetext{
${ }^{15}$ The hunting tribes have traditionally been employed by the upper castes- the Rajputs for instance, who were the historical rulers and then followed by the Mughals, both of whom recruited the artful tribes in their armies. Even through the British rule and later in independent India the hunting communities have been relied upon for bringing fresh meat from the forest as one of the areas of historical collaboration between the rulers and the ruled, between forest and the non-forest communities or between local 'experts' of the forests and the powerful 'inexperts' from the non-forest backgrounds.
} 
Guha, R. (2014). The Indian Road to unsustainability. The Telegraph (August 9). Retrieved from http://ramachandraguha.in/archives/the-indian-path-to-unsustainability-thetelegraph.html. [Accessed on 11.01.2015]

---. (2011). The Environmental Challenge, in, The Telegraph. Retrieved from http://ramachandraguha.in/archives/the-environmental-challenge.html. [Accessed on 11.01.2015].

---. (1999). Environment and Ethnicity in India, 1200-1991. Cambridge: Cambridge University Press. [Also see, Doshi, S. L. (2005[1978]) 'A Sociological Analysis of Political Unification among the Scheduled Tribes of Rajasthan', in Chacko, P. M. (ed.) Tribal Communities and Social Change (pp. 134-147). New Delhi and London: Sage Publications.

Haldon, J. (1993). The State and the Tributary Mode of Production. London: Verso.

Jain, A. and Katewa, SS; Galav, PK and Nag, A. (2007). Unrecorded Ethnomedicinal Use of Biodeiversitiy. Tadagarh-Raoli Wildlife Sanctuary, Rajasthan. ActaBotanicaUnannica, 29 (3), 337-344.

Jain, P. (1991). Social Movements Among Tribals: a Sociological Analysis of Bhils of Rajasthan. Udaipur: Rawat Publications.

Khagram, S.(2004). Dams and Development: Transnational Struggles for Water and Power. New York: Cornell University Press.

Luthra Sinha, B.(2016). Protestas de Bishnois en Rajhastán occidental: la política de los nuevos movimientos sociales (BSMs) con respect a la democracia india. In

Rodriguez de la Vega, L. and Lavolpe, F. (Comps.). Perspectivas sobre la India: pasados y presentes (pp. 149-198). Lomas de Zamora: UNICOM, Faculty of Social Sciences. National University of omas de Zamora.

---. 2015. In Defense of the endangered Black Buck: Bishnois of India raise the stakes for hunters and poachers in Western Rajasthan. Senri Ethnological Studies (Forthcoming). SES. National Museum of Japan. [See, http://www.minpaku.ac.jp/english/research/activity/publication/other/ses].

Nilsen,A. G.(2015).Subalterns and the State in the Longue Durée: Notes from "The Rebellious Century" in the Bhil Heartland. Journal of Contemporary Asia, 45 (4), 574595. Special Issue: Rethinking Resistance: Subaltern Politics and the State in Contemporary India.

Skaria, A. (1998). Being Jangli: The Politics of Wildness. Studies in History, 14 (2), 193215.

Skaria, A. (1999). Hybrid Histories: Forests, Frontiers and Wildness in Western India. Delhi: Oxford University Press.

Singh, K. (1985). Tribal Society in India: An Anthropo-Historical Perspective. Delhi: Manohar.

Singh, K.S.(Ed.). (1998). People of India. Rajasthan. Part two. Volume XXXVIII. Anthropological Survey of India. Popular Prakashan. Mumbai. India. S[ee, Foreword $\mathrm{XVI-} X X \mathrm{VII}$.

Singh, M.H. (2013). The Castes of Marwar. Census Report 1891. Introduction, komal Kthari. [See section on Bhils (pp.55-58); Section on Ban Bavris (pp.60-66)]. Jodhpur. India: Bharat Printers. 


\section{Reports/ Census/Constitution}

Nomadic Report. Retrieved from http://www.hic sarp.org/documents/NomadicReport.pdf. [Accessed 19.01.2015]

National Advisory Council Working Group on De-notified and Nomadic Tribes Report. Retrieved from http://www.nirmanindia.org/Report/dnt_draft.pdf. [Accessed 19.01.2015].

Database: General report on the Census of India, 1891.

Census of India, 2001 - Tables on Individual Scheduled Castes (SC) and Scheduled Tribes (ST).

Census of India, 2001. Rajasthan, Data Highlights: The Scheduled Tribes.

The Constitution(Scheduled Castes) Order, 19501 (C.O.19) Part XV. 